\title{
New Radiocarbon Dates from East Texas Caddo Sites
}

Timothy K. Perttula

Heritage Research Center, Stephen F. Austin State University

Robert Z. Selden Jr.

Heritage Research Center, Stephen F. Austin State University

Follow this and additional works at: https://scholarworks.sfasu.edu/ita

Part of the American Material Culture Commons, Archaeological Anthropology Commons, Environmental Studies Commons, Other American Studies Commons, Other Arts and Humanities Commons, Other History of Art, Architecture, and Archaeology Commons, and the United States History Commons

Tell us how this article helped you.

This Article is brought to you for free and open access by the Center for Regional Heritage Research at SFA ScholarWorks. It has been accepted for inclusion in Index of Texas Archaeology: Open Access Gray Literature from the Lone Star State by an authorized editor of SFA ScholarWorks. For more information, please contact cdsscholarworks@sfasu.edu. 


\section{New Radiocarbon Dates from East Texas Caddo Sites}

Creative Commons License

(c) (i) (8)

This work is licensed under a Creative Commons Attribution-NonCommercial 4.0 International License 


\title{
New Radiocarbon Dates from East Texas Caddo Sites
}

\author{
Timothy K. Perttula and Robert Z. Selden, Jr.
}

\section{INTRODUCTION}

In this article, we report the results of AMS dating of organic remains from ancestral East Texas Caddo sites in Gregg and Harrison counties. These sites are the Wade site (GC-38), a Middle Caddo period habitation in the mid-Sabine River basin (Perttula et al. 2014a), as well as from vessels (in the Gregg County Historical Museum) placed in Caddo burials at the Susie Slade (41HS13), Hyte, Eli Fields, J. O. and Henry Brown (41HS261), and the Patton (41HS825) sites in the Big Cypress and mid-Sabine River basins (Perttula et al. 2014b), and a vessel from an unknown site in the Big Cypress Creek basin (Perttula et al. 2014c).

\section{NEW RADIOCARBON DATES}

The Wade site radiocarbon date (D-AMS 003662) is on a piece of unburned turtle shell found at a depth of $56 \mathrm{~cm}$ bs in Middle Caddo period midden deposits. As best as can be determined from the decorated sherd assemblage and a clay pipe from the Wade site, the principal ancestral Caddo domestic settlement at the site predates ca. A.D. 1450, possibly dating between ca. A.D. 1300-1450 (Perttula et al. 2014a). The engraved fine wares, and the incised-punctated variant of Washington Square Paneled at the Wade site, are like ceramic assemblages on Middle Caddo period (ca. A.D. 1200-1450) sites in the mid-Sabine and Angelina River basins (cf. Gadus et al. 2006; Hart 1982; Perttula and Nelson 2013; Walters 2008, 2010). The one radiocarbon date has calibrated 2 sigma age ranges of A.D. 1278-1316 (0.51) and A.D. 1355-1390 (0.45), and a median calibrated age of A.D. 1312.

The Susie Slade site (41HS13) is an 18th century Historic settlement and cemetery on a sandy knoll in the Potters Creek valley in the Sabine River basin. Jones (1968) excavated three burials of historic age (i.e.,, post-A.D. 1685) at the site. The site is known to have had a large cemetery ( $>50$ burials) that was excavated by a number of East Texas collectors and amateur archaeologists. These burials were spaced from 1.8-4 m apart, and they were oriented in extended supine position in east-west pits, with the head of the deceased facing to the west or southwest (Jones 1968:102).The two radiocarbon dates from the Susie Slade site are on organic residues that was adhering to the exterior surface of two different vessels. The first 2 sigma calibrated date has an age range (D-AMS 003663) of A.D. 1652-1880 and is on a medium-sized jar in Burial 1 that is decorated with five horizontal and vertical rows of tool punctations (Figure 1). The vessel body has incised chevrons that are repeated six times around the vessel and extend nearly to the base. The second calibrated date (D-AMS 003664), with an age range of A.D. 1662-1811, is on a very large La Rue Neck Banded jar from Burial 2 (Figure 2).

The median calibrated dates from the two vessels at the Susie Slade site range between A.D. 1769-1774, indicating a late 18th century use of the vessels before they were interred in Burials 1 and 2. The likeliest probabilities of the two calibrated dates fall between A.D. 1720-1819 and A.D. 1728-1811. 


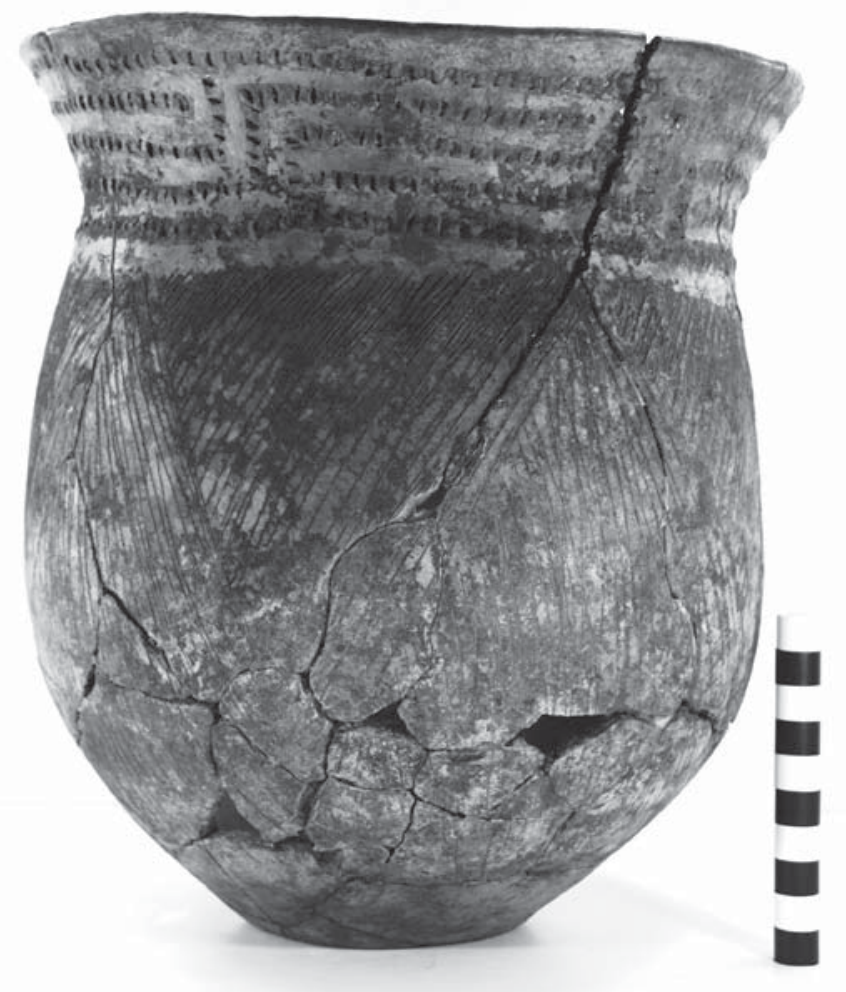

Figure 1. Incised-punctated jar from Burial 1 at the Susie Slade site.

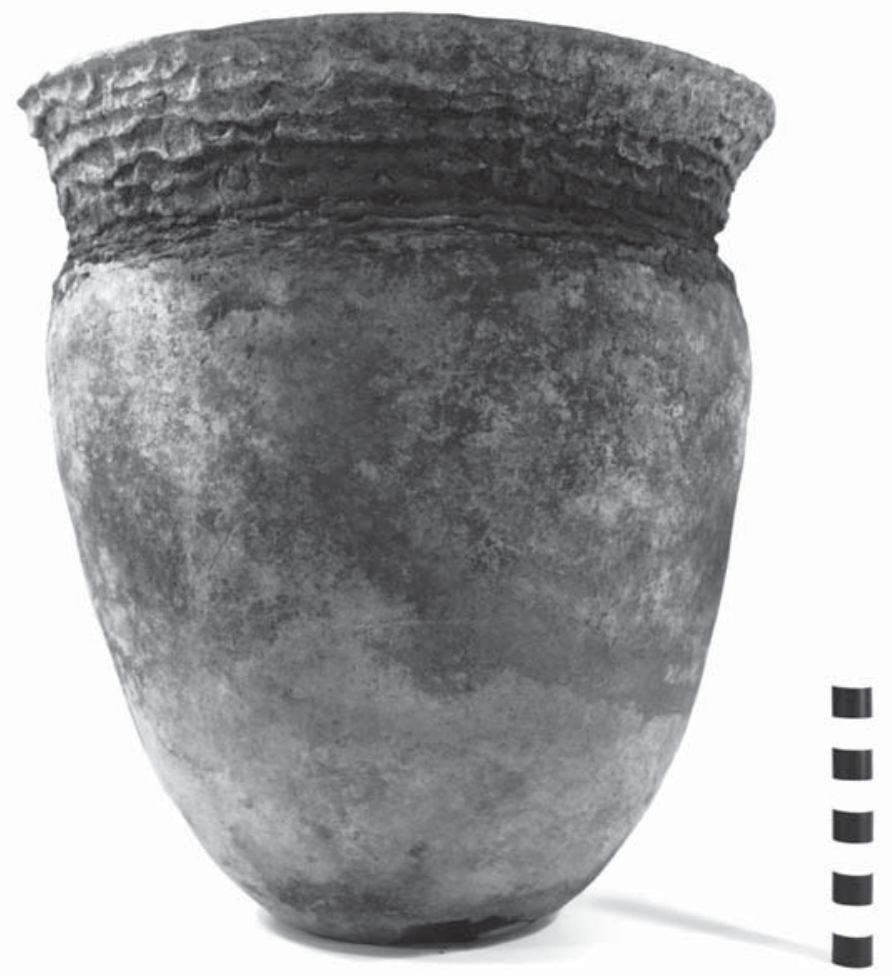

Figure 2. La Rue Neck Banded jar from Burial 2 at the Susie Slade site. 
One radiocarbon date is from organic residue on a Cass Appliqued jar found in a burial (Burial 3) at the Hyte site (D-AMS 003665). The 2 sigma calibrated age range is A.D. 1484-1644, with a median calibrated date of A.D. 1564. The very short rim is plain, but the vessel body has a continuous series of vertical appliqued ridges (Figure 3). The Hyte site is an ancestral Caddo cemetery on Panther Creek in northern Gregg County. Panther Creek is a northward-flowing tributary to Little Cypress Creek. The utility ware and fine ware vessels from the site are indicative of a Late Caddo period (ca. A.D. 1430-1680), Titus phase cemetery in the Big Cypress Creek heartland (cf. Fields and Gadus 2012:Figure 9.12). The principal fine wares at the Hyte site include several varieties of Ripley Engraved, Wilder Engraved, and Turner Engraved, and utility wares include Pease Brushed-Incised and an assortment of incised, appliqued, punctated, and brushed jars.

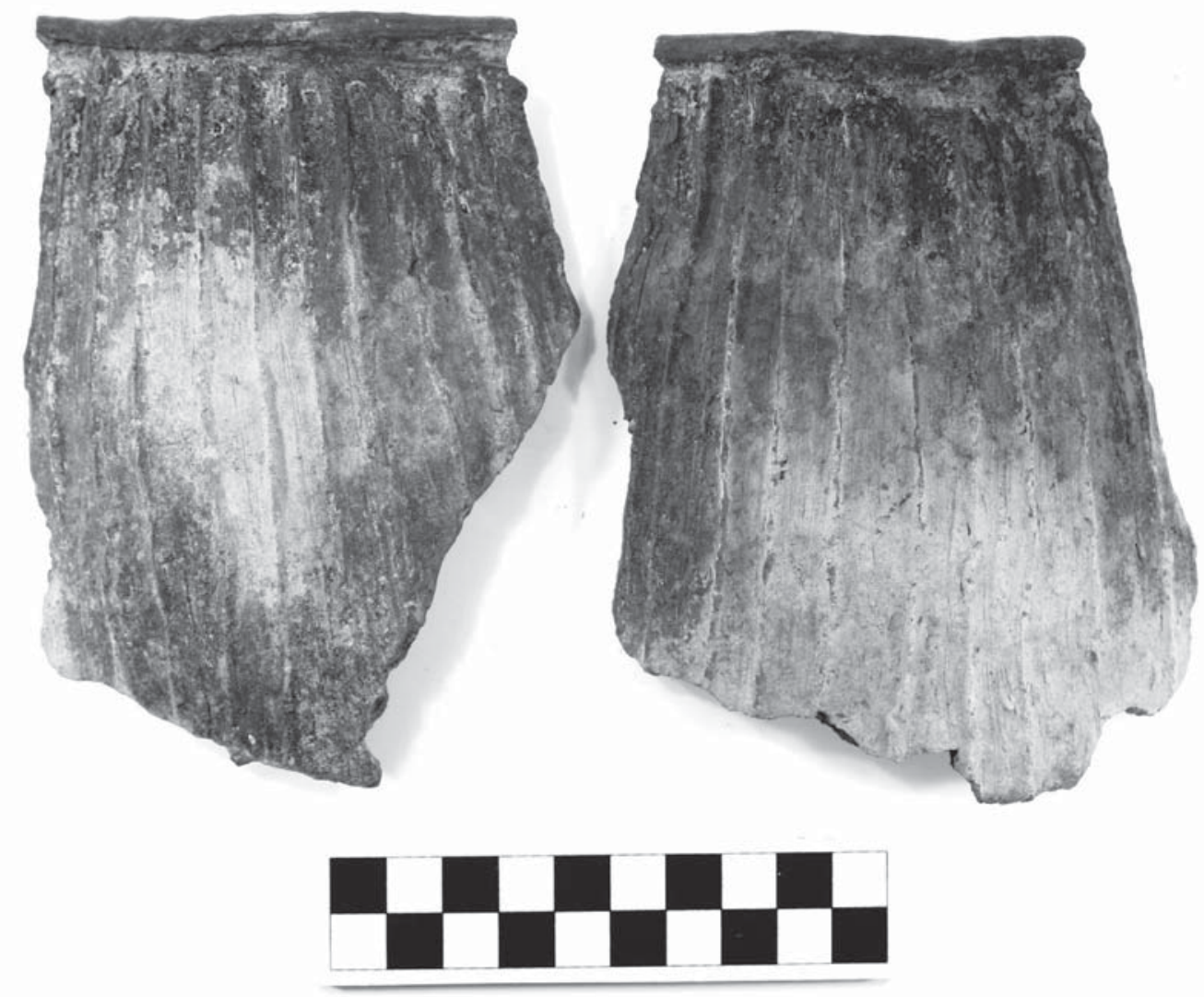

Figure 3. Cass Appliqued jar from Burial 3 at the Hyte site.

The Eli Fields site is on a Hatley Creek alluvial terrace in the Sabine River basin. The vessels from the Eli Fields site include plain wares, utility wares (brushed, brushed-punctated-incised, Bullard Brushed, and Pease Brushed-Incised) and fine wares. None of the fine wares are typologically identifiable but decorative elements include semi-circles, arcing lines, brackets, triangles, and ovals, as well as simple horizontal line, scroll, and scroll-circle motifs. Two engraved carinated bowls have a Redwine mode lip (see Walters 2010:Figure 4), a Middle to Late Caddo period lip treatment style in the Sabine River basin. The unique character of the fine wares suggests that the site likely dates from the latter part of the Middle Caddo period, since such diverse and typologically unidentifiable fine wares typify ceramics from this period. The single radiocarbon date (D-AMS 0036666) is from organic residue preserved on the exterior surface of a vessel in Burial 2 at the Eli Fields site. The 2 sigma calibrated age range of the date is A.D. 1410-1453, with a median calibrated date of A.D. 1433. The rim of the Bullard Brushed jar is decorated with horizontal brushing marks and a row of tool punctates at the rim-body juncture. The vessel body has diagonal brushed-incised marks that extend to the base with a set of two overlapping diagonal incised lines (Figure 4). 


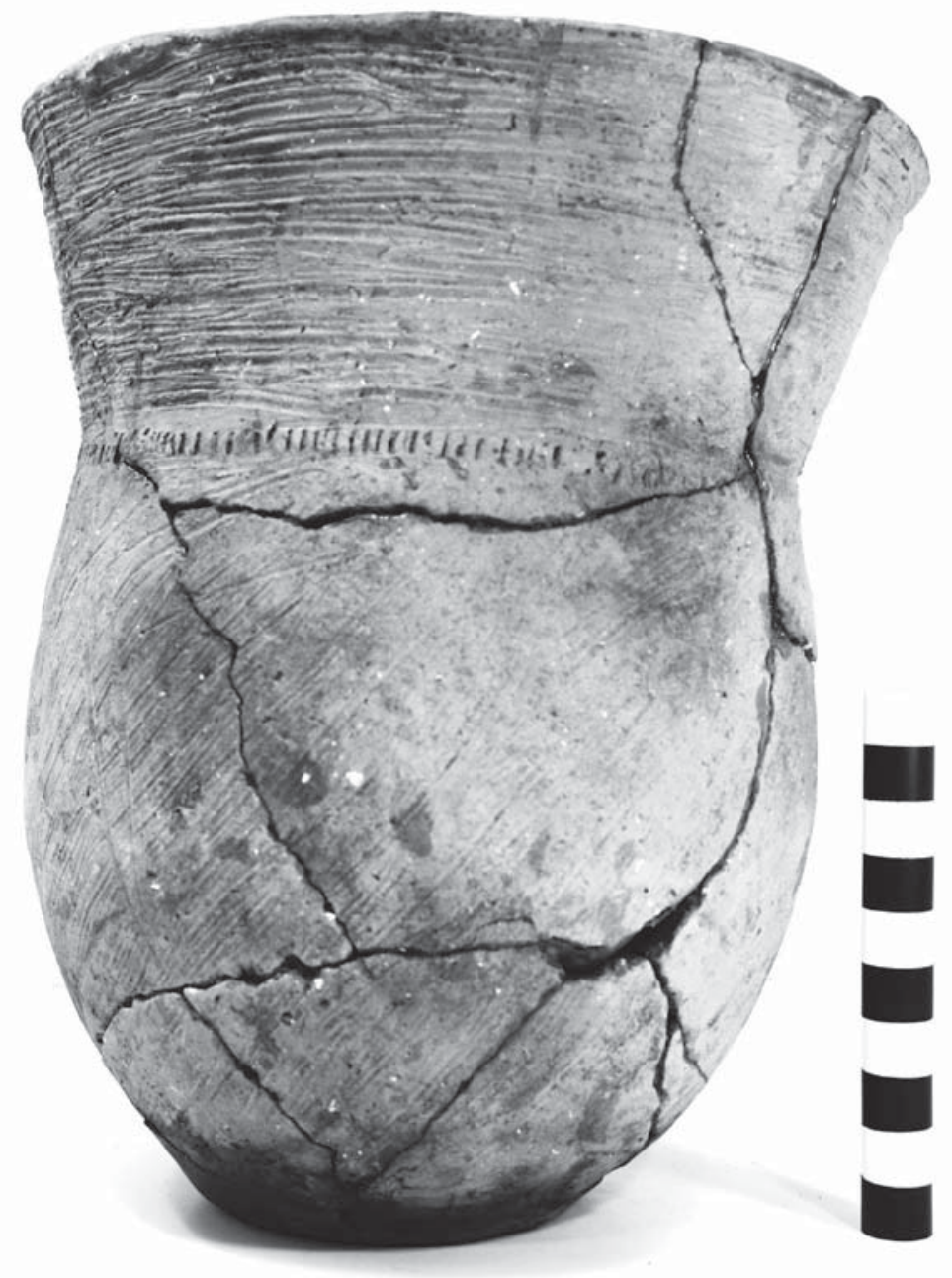

Figure 4. Bullard Brushed jar from Burial 2 at the Eli Fields site.

The J. O. and Henry Brown site (41HS261), also referred to as the Brown Burial Site 1, was first documented and excavated by Jones (1968). His work was in an ancestral Caddo cemetery with at least nine burials on an alluvial terrace on the west side of Potters Creek, a southern-flowing tributary to the Sabine River. According to Jones (1968), three of the nine burials known to have been excavated at the J. O. and Henry Brown site contained European trade goods (glass beads and iron knives from Burials 1, 3, and 9) as well as aboriginal funerary objects (ceramic vessels, a clay pipe, chipped stone knives and arrow points), and a red ochre mass.

Ceramic fine wares from the J. O. and Henry Brown site identified in the collections include Hodges Engraved, Keno Trailed, Natchitoches Engraved (Burial 4), Patton Engraved (in Burials 4, 8, and 9), Simms Engraved, and Taylor Engraved; Simms Engraved carinated bowls are particularly common. Utility wares include Bullard Brushed, Emory Punctated, and Maydelle Incised jars. One radiocarbon date (D-AMS 003667) has been obtained on organic residue from a vessel found in Burial 5 at the J. O. and Henry Brown site. The rim of the Emory Punctated jar is decorated with three rows of tool punctates (see Jones 1968:Plate 26b). The 2 sigma calibrated age range of the residue on this jar is A.D. 1484-1644, solidly in the Late Caddo period, with a median calibrated date of A.D. 1564. 
The Patton site is an ancestral Caddo settlement with several habitation areas and an associated cemetery on an alluvial terrace of Arms Creek, a northern-flowing tributary to Big Cypress Creek in the Lake O' the Pines area. Buddy C. Jones located and excavated the site in 1964, including the investigation of a total of eight burials (Burials 1-8) with a number of funerary offerings. Since Jones' work, extensive looting of more Caddo burials (ca. 88 or more) from this Late Caddo Titus phase community cemetery has taken place (Perttula 2012:Table 13-3).

Identified utility and fine wares in the Patton site are consistent with a Late Caddo period Titus phase component, one where most of the burials apparently date after ca. A.D. 1550. Utility wares include Belcher Ridged, Bullard Brushed, Karnack Brushed-Incised, La Rue Neck Banded, Moore Noded, Pease BrushedIncised, and appliqued rattle bowls, while fine wares consist of Bailey Engraved, cf. Hodges Engraved, Ripley Engraved, var. Gandy, var. Pilgrims, and var. McKinney, Simms Engraved, Taylor Engraved, and Wilder Engraved. The two radiocarbon dates from the Patton site are on organic residue adhering to the surface of two different vessels. The first date (D-AMS 003668) is on a Pease Brushed-Incised jar from Burial 1, and the 2 sigma calibrated age range is A.D. 1458-1635, with a median calibrated date of A.D. 1558. The rim panel of this small vessel has upper and lower horizontal incised lines and a continuous series of vertical incised lines. The vessel body is divided into 13 panels by vertical appliqued ridges. The body panels are filled with vertical brushed-incised marks (Figure 5). The second radiocarbon date (D-AMS 003669) is on a Karnack Brushed-Incised vessel in Burial 6. This date is older than the first, with a 2 sigma calibrated age range of A.D. 1330-1441; the median calibrated date is A.D. 1419. The vessel is decorated with vertical brushing marks from the short rim to the vessel base (Figure 6).

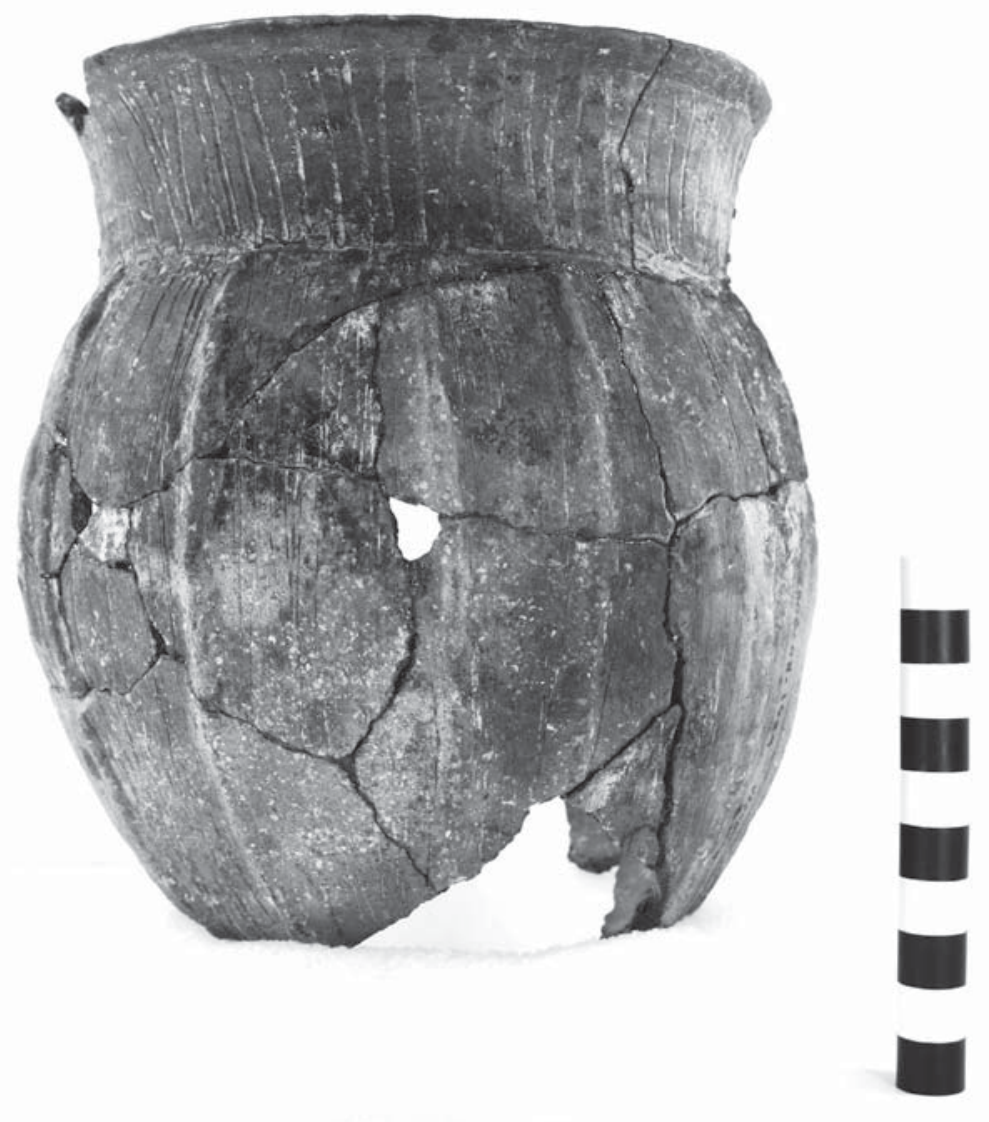

Figure 5. Pease Brushed-Incised jar from Burial 1 at the Patton site. 


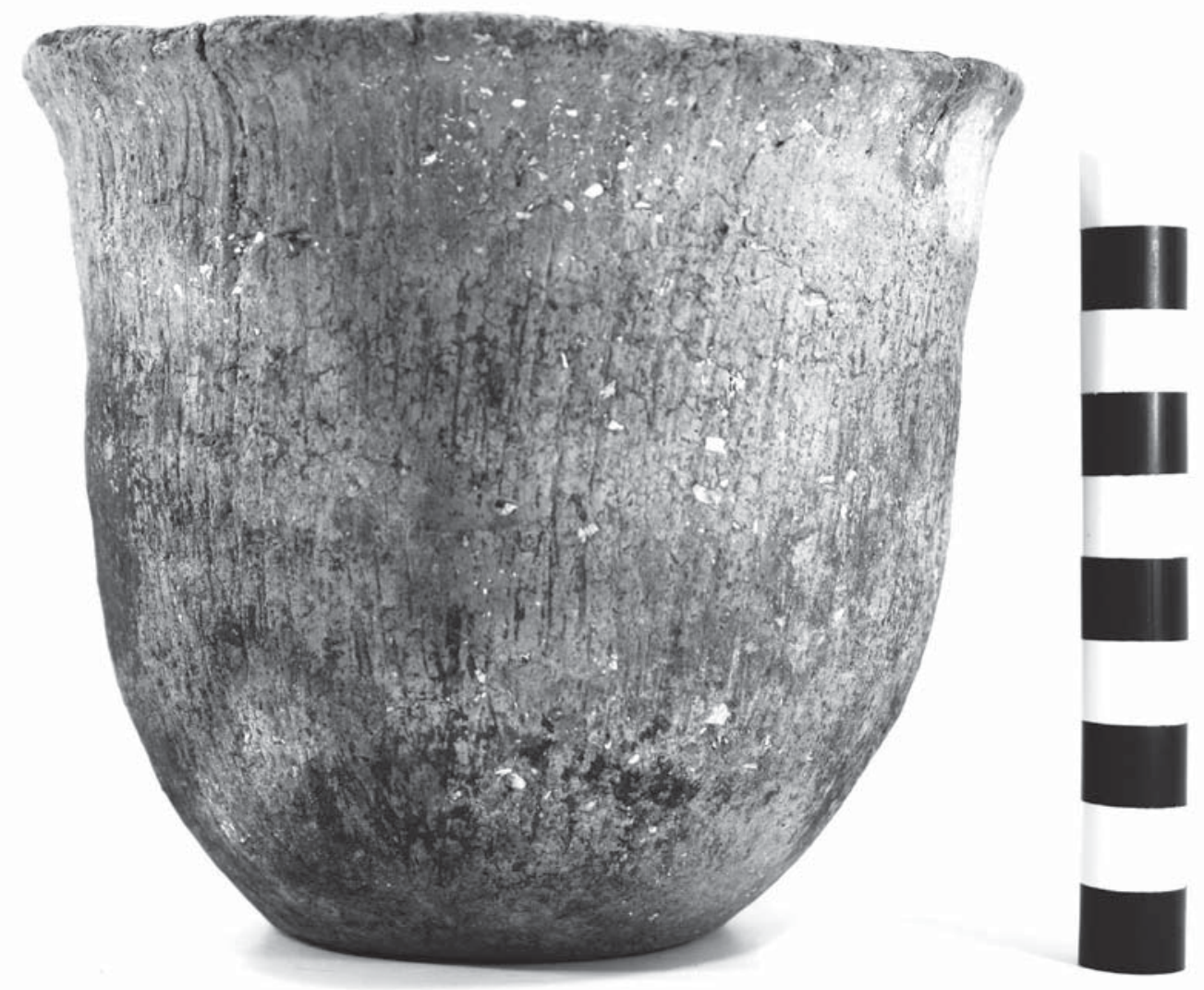

Figure 6. Karnack Brushed-Incised jar from Burial 6 at the Patton site.

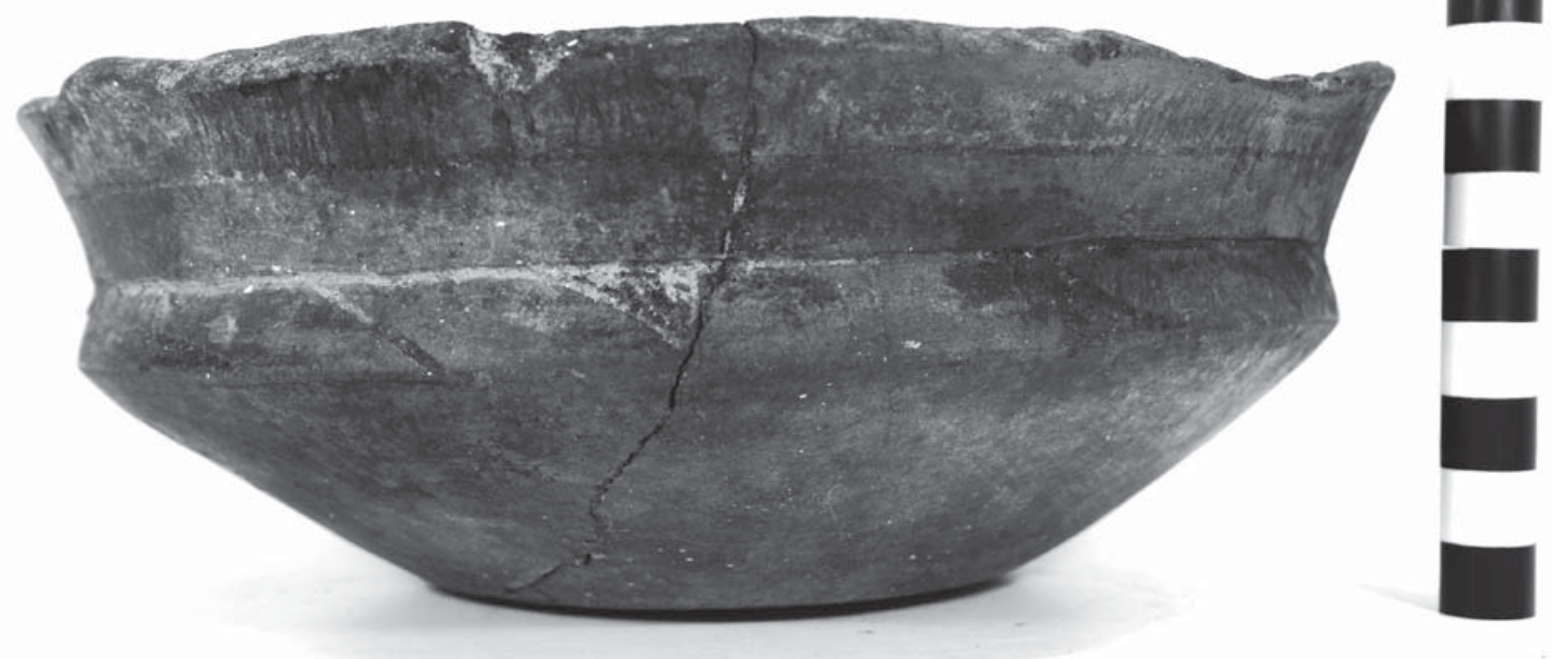

Figure 7. Turner Engraved, var. unspecified compound bowl from the Titus phase series of vessels in the Buddy Calvin Jones collection. 
The last new radiocarbon date (D-AMS 003670) is from a Turner Engraved, var. unspecified compound bowl (Figure 7) in the Titus phase series of vessels in the Buddy Calvin Jones collection at the Gregg County Historical Museum (Perttula et al. 2014c). Such vessels have been found in ca. A.D. 1430-1680 Titus phase sites in the Big Cypress Creek basin in East Texas. The 2 sigma calibrated age range of the residue on this Turner Engraved vessel is A.D. 1426-1616, but the highest probabilities are associated with an age range of A.D. 1426-1499. The median calibrated date is A.D. 1455.

\section{SUMMARY}

Nine new radiocarbon dates have been obtained from six sites, and a vessel from an unknown Late Caddo Titus phase site, in the Big Cypress Creek and mid-Sabine River basins in East Texas. Eight of the dates are on organic residues scraped from the surface of decorated Caddo pottery vessels, and the other date is on a piece of turtle shell from midden deposits at the Wade site.

Three of the dates are from apparent Middle Caddo period (ca. A.D. 1200-1430) contexts at the Wade, Eli Fields, and Patton sites: they have calibrated median ages of A.D. 1312, A.D. 1433, and A.D. 1419, respectively. Four other calibrated radiocarbon dates are from Late Caddo contexts at the Hyte, J. O. and Henry Brown, Patton, and the Turner Engraved vessel from an unknown East Texas site. These have calibrated median ages that range from A.D. 1455 to A.D. 1564. The last two new radiocarbon dates are both from the Historic 18th century Susie Slade site on Potters Creek. The median calibrated dates from the two vessels at the Susie Slade site range between A.D. 1769-1774, with the likeliest probabilities of the two calibrated dates falling between A.D. 1720-1819 and A.D. 1728-1811.

\section{ACKNOWLEDGEMENTS}

Bo Nelson took the photographic images used in this article. Patti Haskins of the Gregg County Historical Museum provided permission to obtain the organic remains from these various Caddo sites for radiocarbon dating.

\section{REFERENCES CITED}

Fields, R. C. and E. F. Gadus (editors)

2012 Archeology of the Nadaco Caddo: The View from the Pine Tree Mound Site (41HS15), Harrison County, Texas. 2 Vols. Reports of Investigations No. 164. Prewitt and Associates, Inc., Austin.

Gadus, E. F., R. C. Fields, J. K. McWilliams, J. Dockall, and M. C. Wilder

2006 National Register Testing of Seven Prehistoric Sites in the Sabine Mine's Area Q, Harrison County, Texas. Reports of Investigations, Number 147. Prewitt and Associates, Inc., Austin.

Hart, J. P.

1982 An Analysis of the Aboriginal Ceramics from the Washington Square Mound Site, Nacogdoches County, Texas. Master's thesis, Department of Anthropology, Northeast Louisiana University, Monroe.

Jones, B. C.

1968 The Kinsloe Focus: A Study of Seven Historic Caddoan Sites in Northeast Texas. Master's thesis, Department of Anthropology, University of Oklahoma, Norman. 
Perttula, T. K.

2012 The Character of Fifteenth- to Seventeenth-Century Caddo Communities in the Big Cypress Creek Basin of Northeast Texas. In The Archaeology of the Caddo, edited by T. K. Perttula and C. P. Walker, pp. 363-410. University of Nebraska Press, Lincoln.

Perttula, T. K. and B. Nelson

2013 Two Middle Caddo Period Habitation Sites and Cemeteries in the Sabine River Basin, Gregg County, Texas. Special Publication No. 27. Friends of Northeast Texas Archaeology, Pittsburg and Austin.

Perttula, T. K., R. Z. Selden, Jr., and B. Nelson

2014a Archaeological Investigations at the Wade (GC-38) and Estes (GC-49) Sites in the Sabine River Basin, Gregg County, Texas. Journal of Northeast Texas Archaeology 45:39-61.

2014b Documentation of Unassociated Ceramic Vessel Funerary Objects in the Gregg County Historical Museum Collections from Sites in Gregg, Harrison, and Panola Counties in East Texas. Special Publication No. 29. Friends of Northeast Texas Archaeology, Pittsburg and Austin.

2014c A Catalog of Selected Caddo Ceramic Vessels in the Buddy Jones Collection at the Gregg County Historical Museum. Special Publication No. 30. Friends of Northeast Texas Archaeology, Pittsburg and Austin.

Walters, M., with contributions from L. G. Cecil, L. S. Cummings, J. P. Dering, J. R. Ferguson, M. D. Glascock,

T. K. Perttula, L. Schniebs, H. J. Shafer, J. Todd, and C. P. Walker

2008 Life on Jackson Creek, Smith County, Texas: Archeological Investigations of a 14th Century Caddo Domicile at the Leaning Rock Site (41SM325). Caddo Archeology Journal 17:1-114.

Walters, M., with contributions by T. Middlebrook and T. K. Perttula

2010 Redwine or Pie-Crust Mode Forms in East Texas Caddo Ceramics and comparisons with Sprocket-Rims of Southwest Arkansas. Caddo Archeology Journal 20:77-128. 